\title{
ASSESSING THE FINANCIAL STATE OF CONSTRUCTION ENTERPRISES
}

\author{
Romualdas Ginevičius, Valentinas Podvezko \\ Vilnius Gediminas Technical University, Saulètekio al. 11, LT-10223 Vilnius, Lithuania \\ E-mail: romualdas.ginevicius@adm.vtu.lt
}

Received 12 December 2005; accepted 15 September 2006

\begin{abstract}
The financial state of construction enterprises can be described by a set of criteria evaluating their commercial activity from various perspectives. The most important of them are solvency and financial risk, including the ratio of current assets to current liabilities, the ratio of current assets minus stocks to current liabilities, the ratio of equity to liabilities, the ratio of assets to liabilities and the ratio of current assets to equity. These values indicate how efficiently various resources, i. e. finances, materials, manpower, etc. are used at an enterprise.

The criteria characterizing the financial state of an enterprise from various perspectives may change in different directions. Moreover, these criteria are multidimensional. Therefore, a problem of finding a unified approach to describe this conflicting situation arises. The particular criteria describe the particular aspects of a complex object. To obtain an integrated estimate of a considered object, multicriteria evaluation methods are applied. Being versatile, these methods are used for solving various problems. A great number of methods evaluating the performance of multidimensional objects have been created and used recently. Each method has some advantages in describing the particular features of an object. Most methods use various techniques for normalization or transformation of the initial data. In the present investigation seven methods of multicriteria evaluation are applied. The calculations made yielded actually the same results, except those obtained by two methods - the sum of ranks and VIKOR. However, the deviation of the data obtained by using these methods from the average value was small. The priority order of enterprises is finally determined integrating the results obtained by all methods used in the present analysis.
\end{abstract}

Keywords: construction enterprise, assessment of the financial state, multicriteria evaluation methods.

\section{Introduction}

In recent years a great number of various criteria has been used to describe the efficiency of enterprise financial management in construction as well as in other branches of industry and economics [1-3]. Paying capacity and financial risk criteria are considered to be the most important. They include the ratios of current assets to current liabilities, current assets minus stocks to current liabilities, equity to liabilities, current assets to equity and assets to liabilities. These ratios show how effectively the financial, material and labour resources are used [2, 4-6].

The values of the above criteria describing enterprise activities from various perspectives do not always change in the same direction, implying that in some cases the financial situation of a firm is improving when the value of the coefficient is growing, while in other cases it is getting better when the coefficient value is decreasing. In addition, the dimensions of the coefficients may also differ. In this envi- ronment the problem of assessing the efficiency of the financial management of construction enterprises arises. The particular criteria relating to a complex phenomenon reflect its essential aspects. To assess a considered object from various perspectives, multiple criteria evaluation methods are widely used. These versatile methods can be applied to solve problems relating to various areas. Different qualitative and quantitative methods are used. Qualitative methods based on expert estimates are aimed at determining one or several best alternatives. Quantitative methods provide quantitative evaluation of each alternative determining the difference between the values of the considered alternatives. Each method has its advantages, emphasizing special characteristics of particular values. Most methods are based on a specific type of normalization or transformation of the initial data (the criteria values).

The main problems to be solved include the normalization of multidimensional criteria, determining their values and 
weights and integrating them into a single criterion. Some problems are also associated with defining the criteria characterizing the considered objects and obtaining the information on a set of generated criteria.

Comprehensive evaluation of various objects and their ranking, based on particular principles, depends both on the criteria values and weights (significances). For example, a normalized value of the criterion may be relatively large, while the contribution of the considered criterion to the total estimate is insignificant, while, vice versa, it may be small, having, however, a great influence on the total estimate. Therefore, quantitative evaluation of the criteria weights is of particular importance for complex evaluation.

The determination of the criteria weights is considered to be subjective if it is based on experts' judgements [6-8] and it is thought to be objective, if the particular weight values depend on the structure of the criteria database [7, 8]. Moreover, subjective and objective weights may be integrated [6-10]. The main approach used in the three above mentioned methods is subjective, requiring high qualification of experts because the latter is a decisive factor determining the agreement of their estimates. It should be noted that the estimates may disagree. Therefore, the criteria weights elicited from the experts may be applied to multicriteria evaluation only if the experts' estimates are in agreement [11].

Recently, AHP, a method of pair wise comparison of the criteria, developed by T. Saaty has been widely used $[12,13]$.

\section{The criteria describing the financial position of construction enterprises}

The financial position of an enterprise may be described by the following five ratios representing current assets to current liabilities, current assets minus stocks to current liabilities, equity to liabilities, assets to liabilities and current assets to equity $[2,6]$. Ratios of current assets to current liabilities, current assets minus stocks to current liabilities and equity to liabilities show the enterprise capability to meet the commitments and to convert assets into cash. The ratio of current assets to equity reflects the extent of the financial independence of an enterprise, while the ratio of assets to liabilities indicates that an enterprise can regularly pay dividends.

When the values of the ratios of current assets to current liabilities, current assets minus stocks to current liabilities, equity to liabilities and current assets to equity are decreasing, the financial position of an enterprise is worsening. When the ratio of assets to liabilities is decreasing, the financial position of an enterprise is improving. The relationship between the financial position of an enterprise and the values of financial criteria is presented in detail in Table 1 [5] and Fig 1.

Now, the analysis of time series, allowing for the comparison of the current and previous management results as well as the comparative evaluation based on the comparison of the criteria characterising enterprise performance with those of another similar enterprise are used to assess the efficiency of the financial management of an enterprise. The latter approach is represented by the so-called DELFI (DELPHI) method [14]. However, none of the above methods can allow us to assess the financial management of an enterprise from various perspectives, i. e. to combine various multidimensional criteria into a single integrated criterion describing this process.

Table 1. The approximate assessment levels of the criteria describing the financial position of a construction enterprise

\begin{tabular}{|c|c|c|c|c|c|}
\hline \multirow{2}{*}{ Criterion } & \multicolumn{5}{|c|}{ ASSESSMENT LEVEL } \\
\hline & Very good & Good & Satisfactory & Unsatisfactory & $\mathrm{Bad}$ \\
\hline Overall profitability, \% & $>35$ & $>15$ & $<15$ & $<7$ & negative \\
\hline Own capital profitability, \% & $>30$ & $>20$ & $>10$ & $<10$ & negative \\
\hline Capital profitability, \% & \multicolumn{4}{|c|}{ The higher, the better } & negative \\
\hline $\begin{array}{l}\text { Ratio of current assets to current } \\
\text { liabilities }\end{array}$ & $>2,0$ & $>1,5$ & $>1,2$ & $<1,2$ & $<1,0$ \\
\hline $\begin{array}{l}\text { Ratio of current assets minus stocks to } \\
\text { current liabilities }\end{array}$ & $>1,5$ & $>1,2$ & $>1,0$ & $<1,0$ & $<0,5$ \\
\hline Ratio of equity to liabilities & $>2,0$ & $>1,5$ & $>1,0$ & $<1,0$ & $<0,5$ \\
\hline Ratio of current assets to equity & 0,6 & 0,5 & 0,4 & 0,3 & 0,1 \\
\hline Ratio of assets to liabilities, \% & $<30$ & $<50$ & $<70$ & $>70$ & $>100$ \\
\hline Stock turnover & \multicolumn{5}{|c|}{ The higher, the better } \\
\hline Fixed assets turnover & $>1,5$ & $>1,0$ & 1,0 & $<1,0$ & \\
\hline $\begin{array}{l}\text { The ratio of accounts receivable to the } \\
\text { total debt }\end{array}$ & \multicolumn{5}{|c|}{ The higher, the better } \\
\hline Total assets turnover & $>2,0$ & $>1,0$ & 1,0 & $<1,0$ & \\
\hline
\end{tabular}




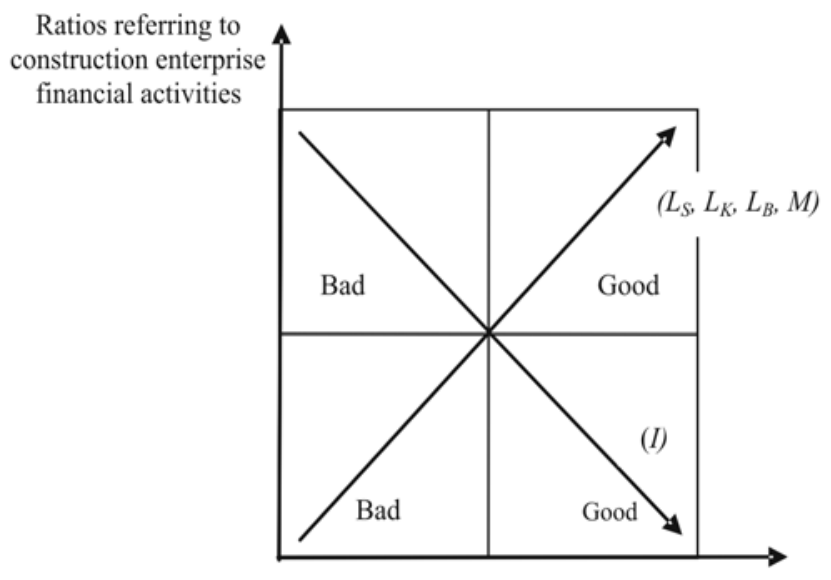

Financial state of an enterprise

Fig 1. The relationship between the financial state of a construction enterprise and the financial indicators (criteria) (the ratios of: $L_{S}$ - current assets to current liabilities, $L_{K}$ - current assets minus stocks to current liabilities, $L_{B}$ - equity to liabilities, $M$ - current assets to equity, $I$ - assets to liabilities)

\section{Methods of evaluating the financial position of con- struction enterprises}

To assess the efficiency of enterprise performance, a great number of qualitative and quantitative multicriteria methods have been created and used. Quantitative methods are based on the construction of a matrix containing the criteria of an object, statistical data or estimates elicited from experts, $\mathbf{R}=\left\|r_{i j}\right\|, i=1, \ldots, m ; j=1, \ldots, n$, where $m$ is the number of the criteria and $n$ is the number of the compared objects. When applying these methods, it should be stated whether the criteria to be used are maximized or minimized. For maximized criteria the largest values are the best, while for minimized criteria the smallest values are better. In various methods, different kinds of the initial data (values of the criteria) normalization or transformation are applied. Some methods are more complicated than others.

In the present analysis, seven multicriteria evaluation methods are used.

1. The sum of all criteria ranks (SR) $V_{j}$ for each $j$-th object (enterprise). This is calculated from the formula [1516]:

$$
V_{j}=\sum_{i=1}^{m} m_{i j},
$$

where $m_{i j}$ is the rank of the $i$-th criterion for the $j$-th object $\left(1 \leq m_{i j} \leq m\right)$. One can see in formula (1) that the best value of $V_{j}$ is the smallest. If some of $m_{i j}$ values are the same, each object is given the same value (rank) which is the closest average value of these objects. For example, if three objects were ranked the same, based on the $i$-th criterion, and their priority order was 4, 5 and 6 , then, they are given the same value (rank) $m_{i j}=5$. If the same values of the $i$-th criterion are obtained for the ranks 9, 10, they both are given the value 9.5. The values of the criterion $V_{j}$ do not depend either on the normalization of the initial data, scale, transformation or on the values of criteria $\omega_{i}(i=1, \ldots, m)$. However, the application of this method requires prior determination of the type of the criteria used which may be maximized or minimized. There is also a possibility to convert minimized criteria to maximized ones according to the formula:

$$
\tilde{r}_{i j}=\frac{\min r_{i j}}{r_{i j}},
$$

where $r_{i j}$ is the value of the $i$-th criterion for the $j$-th object. Then the smallest criterion value will become the largest value equal to one.

The calculations have shown that this criterion is the simplest and may be used only for preliminary evaluation. However, in many cases the results yielded by this method do not differ considerably from those obtained in other methods.

2. SAW (Simple Additive Weighting). In this method, the sum of the weighted normalized values of criteria $S_{j}$ is calculated for each $j$-th object. It is obtained from the following formula [7]:

$$
S_{j}=\sum_{i=1}^{m} \omega_{i} \tilde{r}_{i j},
$$

where $\omega_{i}$ is the weight of the $i$-th criterion; $\widetilde{r}_{i j}$ is the normalized value of the $i$-th criterion for the $j$-th object.

In this case, the normalization of the initial data is made according to the formula $[4,7]$ :

$$
\tilde{r}_{i j}=\frac{r_{i j}}{\sum_{j=1}^{n} r_{i j}}
$$

where $r_{i j}$ is the value of the $i$-th criterion for the $j$-th object.

For rough calculations the weights of all criteria may be assumed to be the same, i. e. $\omega_{i}=\frac{1}{m}$, where $m$ is the number of the criteria. The best value of $S_{i}$ is the largest value.

3. Geometric mean (GM) $\Pi_{j}$ is calculated from the formula $[15,16]$ :

$$
\Pi_{j}=\sqrt[m]{\prod_{i=1}^{m} \tilde{r}_{i j}}
$$

The priority order established based on formula (5) does not depend on the value of the criteria weights $\omega_{i}$, therefore, 
it is not necessary to include it into the above formula. The best value of the criterion $\Pi_{j}$ is its highest value.

To assess the performance of the considered enterprises from various perspectives, more advanced and complicated methods, i. e. COPRAS, TOPSIS and VIKOR were used alongside the above described simple approaches.

4. Complex proportional evaluation method (COPRAS) $[17,18]$. According to it, the calculations are made by the formula:

$$
Z_{j}=S_{+j}+\frac{S_{-\min } \sum_{j=1}^{n} S_{-j}}{S_{-j} \sum_{j=1}^{n} \frac{S_{-\min }}{S_{-j}}},
$$

where $S_{+j}=\sum_{i=1}^{m} \omega_{i} \widetilde{r}_{+i j}$ is the largest sum of the weighted values $\widetilde{r}_{+i j}$ of the $j$-th object's maximized values, i. e. those for which the highest value is the best. $S_{-j}=\sum_{i=1}^{m} \omega_{i} \widetilde{r}_{-i j}$ is the same for all minimized criteria of the $j$-th object (their minimum value $S_{-\min }=\min S_{-j}$ ).

5. A simplified version (SKPM) [16] of the proportional evaluation technique (6), allowing the average values $Z_{j}^{*}$ of the criterion $Z_{j}$ to be easily calculated, is offered. According to it, we get:

$$
Z_{j}^{*} \approx S_{+j}+\frac{S_{-\max } S_{-\min }}{S_{-j}} .
$$

The calculations have shown only insignificant differences between $Z_{j}$ and $Z_{j}^{*}$. The priority order of enterprises yielded by both techniques is actually the same.

In calculating the values of criteria $Z_{j}$ and $Z_{j}^{*}$, the type of normalization (4) is used [17].

6. TOPSIS (Technique for Order Preference by Similarity to an Ideal Solution) is based on the principle that the object which is at the shortest distance from the best alternatives and at the longest distance from the worst options is chosen [7, 19]. This method can be used for both maximized and minimized criteria.

TOPSIS is based on vector normalization:

$$
\tilde{r}_{i j}=\frac{r_{i j}}{\sqrt{\sum_{j=1}^{n} r_{i j}^{2}}}(i=1, \ldots, m ; j=1, \ldots, n),
$$

where $\tilde{r}_{i j}$ is a normalized value of the $i$-th criterion of the $j$-th object.

The best alternative $V^{*}$ and the worst alternative $V^{-}$ are calculated by the formula:

$$
\begin{aligned}
& V^{*}=\left\{V_{1}^{*}, V_{2}^{*}, \ldots, V_{m}^{*}\right\}= \\
& =\left\{\left(\max _{j} \omega_{i} \tilde{r}_{i j} / i \in I_{1}\right),\left(\min _{j} \omega_{i} \tilde{r}_{i j} / i \in I_{2}\right)\right\},
\end{aligned}
$$

$$
\begin{aligned}
& V^{-}=\left\{V_{1}^{-}, V_{2}^{-}, \ldots, V_{m}^{-}\right\}= \\
& \left\{\left(\min _{j} \omega_{i} \tilde{r}_{i j} / i \in I_{1}\right),\left(\max _{j} \omega_{i} \tilde{r}_{i j} / i \in I_{2}\right)\right\},
\end{aligned}
$$

where $I_{1}$ is a set of maximized criteria, $I_{2}$ is a set of minimized criteria, $\omega_{i}$ is the weight of the $i$-th criterion $\left(\sum_{i=1}^{m} \omega_{i}=1\right)$.

The total distance $D_{j}^{*}$ to the best alternatives and $D_{j}^{-}$ to the worst alternatives is calculated by the formulas:

$$
\begin{gathered}
D_{j}{ }^{*}=\sqrt{\sum_{i=1}^{m}\left(\omega_{i} \tilde{r}_{i j}-V_{i}^{*}\right)^{2}}, \\
D_{j}^{-}=\sqrt{\sum_{i=1}^{m}\left(\omega_{i} \tilde{r}_{i j}-V_{i}^{-}\right)^{2}} .
\end{gathered}
$$

The main criterion $C_{j}^{*}$ of the method TOPSIS is calculated by the formula:

$$
\begin{gathered}
C_{j}^{*}=\frac{D^{-}}{D_{j}^{*}+D_{j}^{-}}(j=1, \ldots, n) \\
\left(0 \leq C_{j}^{*} \leq 1\right) .
\end{gathered}
$$

The best alternative is associated with the highest value of criterion $C_{j}^{*}$. The compared alternatives should be ranked in the decreasing order.

7. A compromise approach VIKOR [19] also allows the stability intervals of the criteria weights to be established. Like TOPSIS, this method assesses the distance to the ideal solution, but it is not so sensitive to instability of the initial data offering compromise options in the case of conflicting criteria.

VIKOR is based on the following type of normalization:

$$
\begin{gathered}
\tilde{r}_{i j}=\left(\max _{j} r_{i j}-r_{i j}\right) /\left(\max _{j} r_{i j}-\min _{j} r_{i j}\right) \\
\left(0 \leq \tilde{r}_{i j} \leq 1\right) .
\end{gathered}
$$

The method uses three evaluation criteria:

$$
S_{j}, R_{j}, Q_{j} \quad(j=1, \ldots, n) .
$$

Criteria $S_{j}$ and $R_{j}$ are calculated by the formulas:

$$
\begin{gathered}
S_{j}=\sum_{i=1}^{m} \omega_{i} \tilde{r}_{i j}, \\
R_{j}=\max _{i}\left(\omega_{i} \tilde{r}_{i j}\right) .
\end{gathered}
$$

The main integrated criterion $Q_{j}$ is calculated by the formula:

$$
\begin{gathered}
Q_{j}=v\left(S_{j}-S^{*}\right) /\left(S^{-}-S^{*}\right)+ \\
(1-v)\left(R_{j}-R^{*}\right) /\left(R^{-}-R^{*}\right),
\end{gathered}
$$


where

$S^{*}=\min _{j} \mathrm{~S}_{\mathrm{j}}, S^{-}=\max _{j} S_{j}, R^{*}=\min _{j} R_{j}, R^{-}=\max _{j} R_{j}, v$

make the majority criterion or the strategic weight (in this case, $v=0.5$ ).

The best alternatives (enterprises) have the lowest values of criteria $S_{j}, R_{j}$ and $Q_{j}$, implying that the considered alternatives should be ranked in the increasing order.

\section{Complex evaluation of the financial state of construction enterprises}

This evaluation is based on five criteria from Table 2 .

To rank the criteria and to calculate their weights, pairwise comparison technique (AHP) developed by $\mathrm{T}$. Saaty was used when the elements $p_{i j}$ of the mean square matrix $\mathbf{P}$ of criteria $R_{i}$ and $R_{j}(i, j=1, \ldots, m ; m$ is the number of the criteria) range from 1 , if the weights of $R_{i}$ and $R_{j}$ are the same, to $p_{i j}=9$, if the criterion $R_{i}$ is much more significant than the criterion $R_{j}[12]\left(1 \leq p_{i j} \leq 9\right)$.

The finally obtained matrix presenting the comparison of the criteria by experts is illustrated in Table 2 .

The highest real value $\lambda_{\max }=5.04$ in the comparison matrix $\mathbf{P}$ differs insignificantly from the matrix row $m=5$. This means $[12,13]$ that the matrix is in concordance. In fact, the concordance index

$S_{1}=\left(\lambda_{\max }-m\right) /(m-1)=0.014$ and the concordance ratio $S=0,01$ (the ratio of the calculated $S_{1}$ and randomly generated value of the 5th row of the matrix) [12] are much smaller than 0,1 , indicating that the matrix $\mathbf{P}$ is in good concordance.
The calculated criteria values and their ranks are presented in Table 3. The highest weight $\omega_{1}=0,32$ refers to the ratio of current assets to current liabilities, while the lowest weight $w_{5}=0,1$ is associated with the ratio of current assets to equity.

Table 3. Weights and ranks of the criteria characterizing the financial state of the construction enterprise

\begin{tabular}{|c|c|c|c|c|c|}
\hline Criterion No & $\mathbf{1}$ & $\mathbf{2}$ & $\mathbf{3}$ & $\mathbf{4}$ & $\mathbf{5}$ \\
\hline Weight & 0,32 & 0,26 & 0,21 & 0,11 & 0,10 \\
\hline Rank & 1 & 2 & 3 & 4 & 5 \\
\hline
\end{tabular}

The comparative evaluation of the financial state of enterprises is based on two matrices, the first one, $\mathrm{R}=\left\|r_{i j}\right\|(i=1, \ldots, m ; j=1, \ldots, n)$, representing the statistical data of $m$ criteria ( $m=5)$, and $n$ enterprises $(n=4)$, and the second relating to the vector of weights $\omega=\left\|\omega_{i}\right\|$.

Four criteria (i. e. the ratios of current assets to current liabilities, current assets minus stocks to current liabilities, equity to liabilities, current assets to equity) presented in Table 4 are maximized, while one criterion presenting the ratio of assets to liabilities is minimized. Let us apply the techniques based on the sum of ranks (SR), SAW, geometrical mean (GM), complex proportional evaluation (COPRAS) and its simplified version (SKPM), as well as TOPSIS and VIKOR, to the complex evaluation of enterprises.

The values of the criteria describing the financial position of enterprises are presented in Table 4.

Complex evaluation of the financial state of construction enterprises based on formulas $(1-17)$ is given in Table 5 .

Table 2. The matrix of pairwise comparison of the criteria characterizing the financial state of the construction enterprise

\begin{tabular}{|c|l|c|c|c|c|c|}
\hline No & \multicolumn{1}{|c|}{ Criterion } & $\mathbf{1}$ & $\mathbf{2}$ & $\mathbf{3}$ & $\mathbf{4}$ & $\mathbf{5}$ \\
\hline 1 & Ratio of current assets to current liabilities & 1 & 1 & 2 & 3 & 3 \\
\hline 2 & Ratio of current assets minus stocks to current liabilities & 1 & 1 & 1 & 2 & 3 \\
\hline 3 & Ratio of equity to liabilities & $1 / 2$ & 1 & 1 & 2 & 2 \\
\hline 4 & Ratio of assets to liabilities (\%) & $1 / 3$ & $1 / 2$ & $1 / 2$ & 1 & 1 \\
\hline 5 & Ratio of current assets to equity & $1 / 3$ & $1 / 3$ & $1 / 2$ & 1 & 1 \\
\hline
\end{tabular}

Table 4. The values of the criteria characterizing the financial state of construction enterprises

\begin{tabular}{|c|l|c|c|c|c|c|}
\hline No & \multicolumn{1}{|c|}{ Criterion } & Criterion direction & Enterprise 1 & Enterprise 2 & Enterprise 3 & Enterprise 4 \\
\hline 1 & $\begin{array}{l}\text { Ratio of current assets to current } \\
\text { liabilities }\end{array}$ & $\max$ & 1,09 & 1,1 & 1,03 & 1,01 \\
\hline 2 & $\begin{array}{l}\text { Ratio of current assets minus } \\
\text { stocks to current liabilities }\end{array}$ & $\max$ & 0,79 & 0,7 & 0,96 & 1,03 \\
\hline 3 & Ratio of equity to liabilities & $\max$ & 1,56 & 0,4 & 0,4 & 2,2 \\
\hline 4 & Ratio of assets to liabilities (\%) & $\min$ & 64,28 & 70 & 69 & 49 \\
\hline 5 & Ratio of current assets to equity & $\max$ & 0,7 & 2,6 & 2,18 & 0,6 \\
\hline
\end{tabular}


Table 5. Comprehensive evaluation of the financial state of construction enterprises

\begin{tabular}{|c|c|c|c|c|c|c|c|c|c|c|c|c|c|c|c|c|}
\hline $\begin{array}{c}\text { Method, } \\
\text { value, } \\
\text { rank }\end{array}$ & SR & $\stackrel{\mathscr{E}}{\Xi}$ & GM & 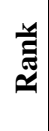 & SAW & 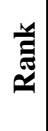 & COPRAS & 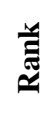 & SKPM & 苑 & TOPSIS & 气 & VIKOR & 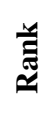 & $\begin{array}{c}\text { Sum } \\
\text { of } \\
\text { ranks }\end{array}$ & $\begin{array}{c}\text { Integ- } \\
\text { rated } \\
\text { rank }\end{array}$ \\
\hline $\begin{array}{c}\text { Enterprise } \\
\mathbf{1}\end{array}$ & 12 & 2 & 0,223 & 2 & 0,250 & 2 & 0,253 & 2 & 0,257 & 2 & 0,52 & 2 & 0,336 & 2 & 14 & 2 \\
\hline $\begin{array}{c}\text { Enterpise } \\
2\end{array}$ & 14 & 4 & 0,212 & 4 & 0,221 & 4 & 0,227 & 4 & 0,231 & 4 & 0,29 & 4 & 0,725 & 3 & 27 & 4 \\
\hline $\begin{array}{c}\text { Enterprise } \\
\mathbf{3}\end{array}$ & 13 & 3 & 0,222 & 3 & 0,231 & 3 & 0,234 & 3 & 0,238 & 3 & 0,30 & 3 & 0,837 & 4 & 22 & 3 \\
\hline $\begin{array}{c}\text { Enterprise } \\
\mathbf{4}\end{array}$ & 11 & 1 & 0,254 & 1 & 0,298 & 1 & 0,286 & 1 & 0,289 & 1 & 0,71 & 1 & 0,300 & 1 & 7 & 1 \\
\hline
\end{tabular}

All methods have shown that the financial state of enterprise 4 is ranked the highest. The estimates of enterprises 2 and 3 do not differ much. According to the five methods applied, enterprise 3 was ranked the third, while two methods yielded the second rank to enterprise 2 . In this case, a result common to all methods should be found.

\section{Conclusions}

The efficiency of financial management of construction enterprises described by the ratios of current assets to current liabilities, current assets minus stocks to current liabilities, equity to liabilities, current assets to equity and assets to liabilities can be determined by using multicriteria evaluation methods allowing diverse and multidimensional financial criteria to be integrated into a single criterion.

The calculations based on various methods of multicriteria evaluation yielded the same result, except for two approaches representing the sum of ranks and VIKOR. However, the latter demonstrated only slight deviation from the average value. The priority order of enterprises is established, integrating the results yielded by all the methods used in the analysis.

\section{References}

1. McLaney, E. J. Business Finance: Theory and Practice (fourth edition). Pitman Publishing. Plymouth, 1997. 422 p.

2. Jones, Charles P. Introduction to Financial Management. North Carolina State University. Boston, 1992. 704 p.

3. Block, Stanley B.; Georffrey A. Hirt. Foundations of Financial Management. IRWIN, 1992. 700 p.

4. Ginevičius, R.; Podvezko, V. Multicriteria evaluation of enterprise financial operations. In: Regional safety and development in international and national context: proceedings (Сборник трудов „Региональная безопасность и развитие в международном и национальном контексте“). Minsk, 2005, p. 40-48 (in Russian).

5. Ginevičius, R.; Podvezko, V. Complex evaluation of the financing activities of construction enterprises. In: Podium: 10 Internationales Kolloquium Planungsinstrumente für das
Projektmanagement am 19 und 20 Mai 2005 in Leipzig: Sonderheft 2005. 11 Jahrgang. 2005, Jg. 11, Sonderheft 1, p. $13-15$.

6. Ginevičius, R.; Podvezko, V. The dependence of multicriteria evaluation results on the criteria weights. In: Proceedings of the National Aviation University (Сборник трудов Национального университета авиации), 2004, № 3, р. 3741 (in Russian).

7. Hwang, C. L.; Yoon, K. Multiple Attribute Decision MakingMethods and Applications. A State of the Art Surwey, Springer Verlag, Berlin, Heidelberg, New York, 1981.

8. Ustinovičius, L.; Zavadskas, E. K. Assessment of investment profitability in construction from technological perspectives (Statybos investicijuc efektyvumo sistemotechninis ivertinimas). Vilnius: Technika, 2004, 220 p. (in Lithuanian).

9. Ma, J.; Fan, Z. P. and Huang, L. H. 'A Subjective and Objective Integrated Approach to determine Attribute Weights'. European Journal of Operational Research, No 112, 1999, p. 397-404.

10. Ustinovičius, L. Determining integrated weights of attributes. Statyba (Civil Engineering), Vol VII, No 4. Vilnius: Technika, 2001, p. 321-326.

11. Podvezko, V. Agreement of Expert Estimates. Technological and Economic Development of Economy (Ūkio technologinis ir ekonominis vystymas), Vol 11, No 2. Vilnius: Technika, 2005, p. 101-107 (in Lithuanian).

12. Saaty, T. L. Fundamentals of Decision Making and Priority Theory with the AHP. RWS Publication, Pittsburgh, PA, USA, 1994.

13. Ginevičius, R.; Podvezko, V.; Andruškevičius, A. Determining of Technological effectiveness of Building Systems by AHP methods. Technological and Economic Development of Economy (Ūkio technologinis ir ekonominis vystymas), Vol 10, No 4. Vilnius: Technika, 2004, p. 135-141 (in Lithuanian).

14. Jantsch, E. Technological Planning and Social Futures. Moscow: Progress, 1974.

15. Ginevičius, R.; Podviezko, V. Complex evaluation of economical-social development of Lithuanian regions. Statyba (Civil Engineering), Vol VII, No 4. Vilnius: Technika, 2001, p. 304-309.

16. Ginevičius, R.; Podvezko, V.; Mikelis, D. Quantitative Evaluation of Economic and Social Development of Lithuanian Regions. In: Economics: proceedings. Vilnius University, 2004, Vol 65, p. 67-81. 
17. Zavadskas, E. K.; Kaklauskas, A.; Raslanas, S.; Malienè, V. Die Anwendung der mehrkriteriellen Methode bei der Bewertung von Erholungsgrundtücken. Statyba (Civil Engineering), Vol VII, No 4. Vilnius: Technika, 2001, p. 327-333.

18. Zavadskas, E. K.; Kaklauskas, A.; Banaitis, A.; Kvederyte, N. Housing Credit Access Model: The Case for Lithuania. Euro- pean Journal of Operational Research, 155, 2004, p. $335-352$.

19. Opricovič, S.; Tzeng, G. H. Compromise solution by MCDM methods: A comparative analysis of VIKOR and TOPSIS. European Journal of Operational Research, 156, 2004, p. $445-455$.

\section{STATYBOS İMONIŲ FINANSINĖS BŪKLĖS KOMPLEKSINIS IৃVERTINIMAS}

\section{R. Ginevičius, V. Podvezko}

\section{Santrauka}

Finansinę statybos įmonių būklę apibūdina daug rodiklių, kurie įvairiais aspektais parodo įmonių komercinès veiklos rezultatus. Labai svarbi vieta tarp jų tenka mokumo ir finansinès rizikos rodikliams. Jiems priklauso einamojo, kritinio, bendrojo likvidumo, isiskolinimo bei manevringumo koeficientai. Savo esme šie dydžiai rodo imonès finansinių, medžiaginių, darbo bei kitokių išteklių naudojimo laipsni.

Minètieji ịvairius įmonès finansinès būklès aspektus apibūdinantys rodikliai kinta priešingomis kryptimis. Be to, jų dimensijos taip pat gali skirtis. Kyla klausimas - kaip tokioje prieštaringoje situacijoje sudaryti apibendrinamajị vaizdą. I sudètingą reiškinį apibūdinančius rodiklius žiūrima kaip i dalinius, perteikiančius esminius jo aspektus. Siekiant apibendrintai ịvertinti nagrinėjamą reiškini, taikomi daugiakriteriniai metodai. Dèl savo universalumo jie taikomi ịvairių sričių uždaviniams spręsti. Šiuo metu sukurta ir taikoma daug sudėtinių dydžiu veiklos efektyvumo kompleksinio įvertinimo metodų. Kiekvienas metodas turi savo privalumų ir išryškina atskiras šiu dydžių ypatybes. Dauguma šių metodų pagrissti skirtinga pradinių duomenų normalizacija arba jų transformacija. Šiame darbe taikyti septyni daugiakriterinio įvertinimo metodai. Apskaičiavus gautas tas pats rezultatas, išskyrus du metodus - vietų sumą ir VIKOR. Kita vertus, ir jie parodė tik nežymų nuokrypi nuo vidurkio. Galutinis įmonių prioritetas nustatomas sujungus visų taikytų metodų rezultatus.

Reikšminiai žodžiai: statybos ịmonè, finansinès būklès įvertinimas, daugiakriteriniai metodai.

Romualdas GINEVIČIUS. Doctor Habil, Professor. Rector of Vilnius Gediminas Technical University (VGTU). A graduate of Vilnius Gediminas Technical University (former Vilnius Civil Engineering Institute) engineering economy (1969), Doctor (1975). Doctor Habil (1997, VGTU). Author of 10 books, monographs, about 150 research articles published in Lithuania and abroad. Member of International Academy of Information.

Research interests: market, economy, theory of organizations.

Valentinas PODVEZKO. Doctor, Associate Professor. Dept of Mathematical Statistics. Vilnius Gediminas Technical University. Doctor (1984). Author and co-author of over 50 publications.

Research interests: sampling and forecasting models in economics. 